\title{
Гравитационный эффект осадочного чехла территории Республики Нигер
}

\author{
(C) 2021 В. Н. Глазнев ${ }^{1,2}$, И. А. Якуба ${ }^{1 凶}$ \\ ${ }^{1}$ Воронежсккий государственный университет, Университетская пл., 1 , \\ 394018, Воронеж, Российская Федерация \\ ${ }^{2}$ Геологический институт Кольского научного центра РАН, \\ ул. Ферсмана, 14, 184209, Апатиты, Российская Федерация
}

\begin{abstract}
Аннотация
Bведение: Рассматриваются подходы и результаты построения геологически содержательной модели осадочного чехла территории Республики Нигер и её обрамления с целью расчёта гравитационного эффекта от осадочной оболочки территории исследований. Аномальное поле чехла необходимо для редуцирования наблюдённого гравитационного поля за счёт плотностных неоднородностей в осадочном чехле.

Строение осадочного чехла региона: Рассмотрены основные особенности строения осадочного чехла территории Республики Нигер. Охарактеризован литологический состав и мощности основных структурных этажей чехла для синеклиз, бассейнов и грабенов Западно-Африканской рифтовой системы. Приведённые сведения использованы при создании модели осадочного чехла территории Республики Нигер и прилегающих стран.

Плотностная модель осадочного чехла: Сводная плотностная модель чехла включает региональные данные о плотности осадочных пород, содержащиеся в модели LITHO1, и детальные данные, сформированные на основе сейсмических материалов 2D ОГТ и петроплотностных исследований по глубоким скважинам региона. Приведена плотностная характеристика слоёв осадочных пород в сводной модели чехла.

Гравитационный эффект осадочного чехла: Выполнен расчёт аномального гравитационного эффекта от сводной цифровой модели осадочного чехла и дана обобщённая морфологическая характеристика аномалий поля. Отмечены особенности аномалий поля в зоне развития грабенов Западно-Африканской рифтовой системы.

Заключение: Сформулированы основные результаты проведённого исследования и намечены задачи вычисления аномального гравитационного порождаемого источниками в кристаллической коре.

Ключевые слова: Республика Нигер, осадочный чехол, гравитационное поле чехла

Для циитирования: Глазнев В.Н., Якуба И.А. Гравитационный эффект осадочного чехла территории Республики Нигер // Вестник Воронежского государственного университета. Серия: Геология. 2021. №2. C. 71-82. DOI: https://doi.org/10.17308/geology.2021.2/3490
\end{abstract}

\section{Введение}

Создание плотностных моделей земной коры крупных континентальных регионов требует использования всей априорной информации об известных глубинных и приповерхностных плотностных неоднородностях изучаемой территории.
Глубинные неоднородности, к которым относится граница раздела кора-мантия, выявляются по результатам интерпретации сейсмологических, сейсмических и гравиметрических данных [1-3 и др.] и дают существенный вклад в аномальное низкочастотное гравитационное поле изучаемого

Контент доступен под лицензией Creative Commons Attribution 4.0 License.

Якуба Ибрагим Абдоу, e-mail: yibrahimabdou@yahoo.fr 
региона [4-8 и др.]. Приповерхностные неоднородности, к которым относятся особенности структуры и плотности пород осадочного чехла, перекрывающего кристаллический фундамент, также дают значительный вклад в суммарное гравитационное поле земной коры $[2,9,10$ и др.], но поскольку эти неоднородности располагаются вблизи поверхности, то они порождают более высокочастотную составляющую гравитационного поля. Учёт гравитационного влияния плотностных неоднородностей чехла носит название «геологического редуцирования» наблюдённого гравитационного поля и, как правило, выполняется при наличии данных о плотностном строении слоёв осадочного чехла. В качестве таковых данных используются результаты сейсмических исследований методом отражённых волн, в модификации общей глубинной точки (ОГТ), и сводные материалы о петрофизических свойствах пород чехла, получаемые по результатам каротажа скважин и лабораторных исследований керна пород [11, 12 и др.]. Однако для многих районов мира детальные сейсмические материалы ОГТ представлены на редкой разрозненной сети профилей, а полнота описания пет- рофизических свойств ограничивается немногочисленными исследованиями по отдельным скважинам. В этих условиях при создании плотностных моделей строения коры крупных регионов следует использовать сводные структурные карты по строению осадочного чехла, обобщённые справочные данные о плотности типичных пород чехла и современные цифровые модели строения осадочной оболочки литосферы Земли $[13,14]$.

Территория Республики Нигер и прилегающих стран Западной и Экваториальной Африки (рис. 1), для которой ранее нами была создана новая интерпретационная модель границы Мохо $[15,16]$ и рассчитано её гравитационное поле, относится к территориям, слабо обеспеченным детальными сейсмическими исследованиями ОГТ. В последнее десятилетие такие исследования, ориентированные на поиски углеводородов, позволили составить геолого-структурные схемы строения чехла для отдельных участков территории Республики Нигер [17-20], которые могут быть использованы для геологического редуцирования аномального гравитационного поля региона.

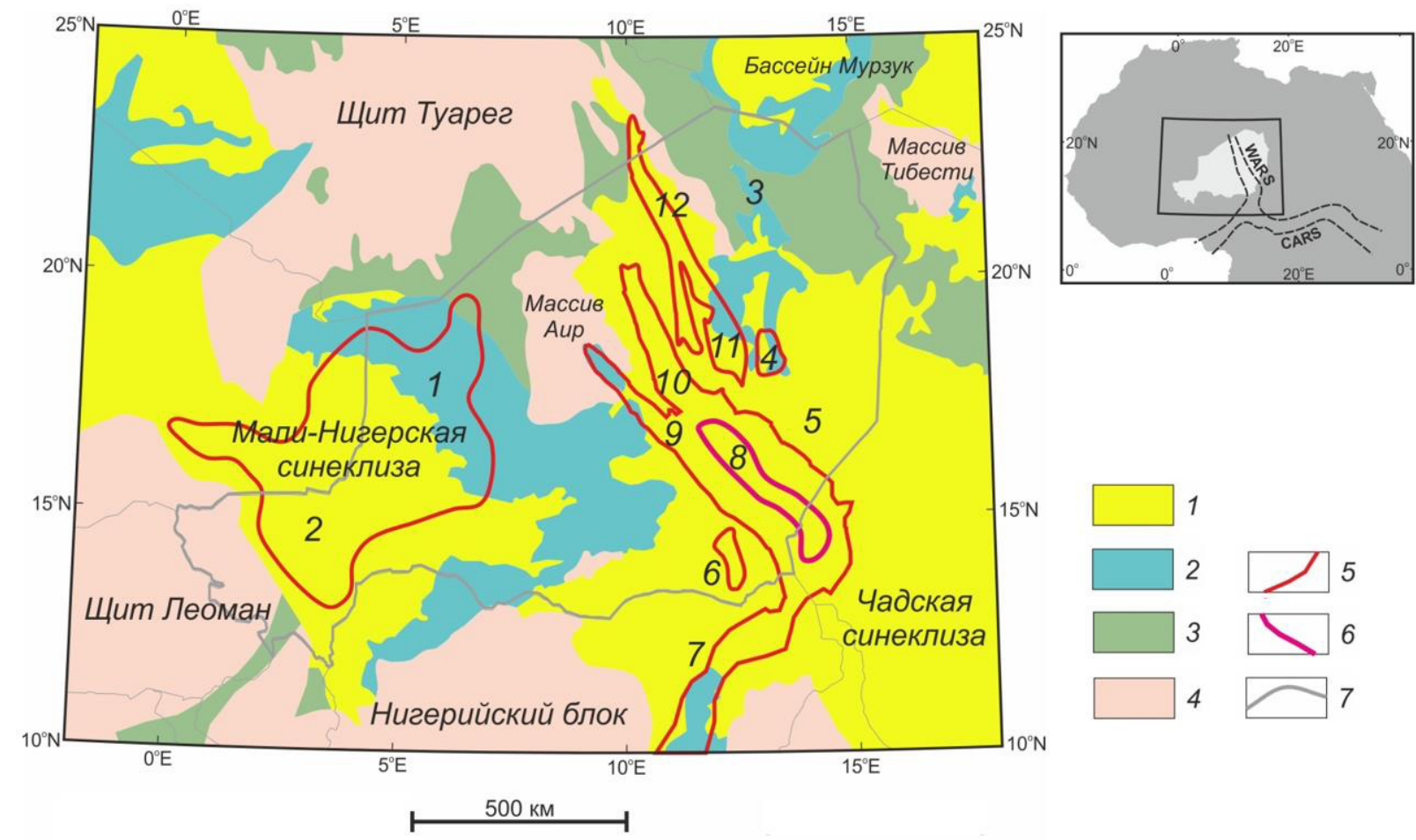

Рис. 1. Геологическая схема территории Республики Нигер и прилегающих стран по [21, 22]. Условные обозначения: 1 - четвертичный период; 2 - мезозой-кайнозой; 3 - палеозой; 4 - протерозой и архей; 5 - контуры грабенов и бассейнов с мощностью осадочного чехла от 1.5 до 10 км; 6 - контуры грабенов с мощность осадочного чехла более 10 км; 7 - государственные границы. Цифрами обозначены: бассейны Тим Мерсои (1), Иуллеммеден (2), Джадо (3), Билма (4), Агадема (5), Нгуэль Элжи (6), Борно (7); грабены Термит (8), Тефидет (9), Тенере (10), Кафра (11), Грейн (12). Аббревиатуры на обзорной схеме: WARS - ЗападноАфриканская рифтовая система; CARS - Центрально-Африканская рифтовая система.

[Fig. 1. Geological map of the Republic of Niger and the neighbouring countries created by [20, 21]. Legend: (1) Quaternary; (2) Mesozoic-Cenozoic; (3) Paleozoic; (4) Proterozoic and Archean; (5) outlines of grabens and basins with a sediment thickness from 1.5 to $10 \mathrm{~km}$; (6) outlines of grabens with a sediment thickness over $10 \mathrm{~km}$; (7) state borders.

Numbers: basins of Tim Mersoi (1), Iullemmeden (2), Djado (3), Bilma (4), Agadem (5), N'Gel Edji (6), and Borno (7); grabens of Termit (8), Téfidet (9), Ténéré (10), Kafra (11), and Grein (12). Abbreviations on the overview map: (WARS) West African Rift System; (CARS) Central African Rift System.] 
В предлагаемой работе рассматриваются исходные данные, методы и результаты расчёта гравитационного эффекта осадочного чехла для территории Республики Нигер в условиях неполноты исходной геолого-геофизической информации. Основной задачей такого геофизического моделирования является создание региональной схемы гравитационных аномалий, в которой будет исключено гравитационное влияние границы Мохо $[15,16]$ и влияние гравитационного поля осадочного чехла для территории Республики Нигер и прилегающих регионов. Указанные гравитационные аномалии послужат основой при детальном изучении геологического строения кристаллической коры территории Республики Нигер и выявления пространственных закономерностей размещения основных видов полезных ископаемых, связанных с внутрикоровыми процессами.

\section{Строение осадочного чехла региона}

Современная структура коры севера Африканского континента (рис. 1) является результатом геологической эволюции литосферы региона, длящейся уже более 3 млрд лет. Этапы развития литосферы, согласно [21], включают: образование ювенильной коры и стабилизацию кратонов северной Африки в архейское время; переработку коры в протерозойское время; последующий Панафриканский орогенез (в интервале 450-600 млн лет) и перегруппировку блоков. На этом этапе эволюции завершается формирование ЗападноАфриканского кратона и Восточно-Сахарского мегакратона с разделяющей их Западно-Африканской мобильной зоной. В мезозойскую эру последовал распад суперконтинента Гондвана, а в кайнозое имел место подъём горячего мантийного материала в области Западно-Африканской мобильной зоны, проявленный на поверхности в виде молодого вулканизма, и реактивации тектонических процессов с формированием Западно-Африканской и Центрально-Африканской рифтовой систем. Современные осадочные бассейны региона, сформированные в процессе последней реактивации [22], рассмотрим более подробно, поскольку они являются основным объектом нашего исследования, ориентированного на расчёт гравитационного эффекта приповерхностных геологических структур.

Мали-Нигерская синеклиза (рис. 1), в которой выделяют северную и южную часть (бассейны Тим Мерсои и Иуллеммеден), сложена морскими и континентально терригенными породами от триасового до палеоцен-эоценового возраста [23]. Мощность осадочных пород в бассейне Тим Мерсои плавно увеличивается к центру бассейна, где достигает величины около 2000 м, и включает мезозойские стратифицированные континентальные и морские серии, основную часть которых составляют нижнемеловые и юрские отложения. Осадочные породы бассейна представлены песками, песчаниками, глинистыми песками, глинами, глинистыми сланцами, мергелями и известняками, причём мощности отдельных литологических разностей составляют от первых метров до первых сотен метров [24-27]. Для бассейна Иуллеммеден характерно наличие мощных толщ верхнемеловых и палеогеновых пород, представленных континентальными и осадочными комплексами песчаников, глинистых песчаников, глинами, переходящими в песчано-глинистые илы или илистые глины, отмечается также присутствие мергелей и меловых отложений $[28,29]$. Структура бассейна Иуллеммеден несимметричная с увеличением мощности чехла до 2500-3000 м в его южной части, где отмечается также более крутое падение стратифицированных толщ осадков с мощностью до первых сотен метров. В целом для Мали-Нигерской синеклизы характерно несимметричное строение с увеличением суммарной мощности осадочного комплекса до 3000 м в южной его части за счёт интенсивного накопления терригенных и осадочных верхнемеловых и палеогеновых пород [29]. К сожалению, сводных структурных карт изопахит для Мали-Нигерийской синеклизы не имеется, а все прогнозные построения ограничиваются отдельными обобщёнными схематическими геологическими разрезами, отражающими отмеченные тенденции строения бассейна.

Разрез Чадской синеклизы, в основании которой залегают породы меловой континентальной серии, в целом аналогичен разрезу Мали-Нигерской синеклизы, и состоит из четырёх суббассейнов: Агадема, Билма, Джадо и собственно бассейна озера Чад [17, $22,30,31]$. Осадочные породы Чадской синеклизы, сложенные стратифицированными образованиями континентальных и, в меньшей мере, морских серий с возрастами от меловых до четвертичных, представлены глинами, глинистыми песчаниками, песками и карбонатами. Наибольшей мощностью чехла, достигающей 2000-2500 м, отличается собственно бассейн озера Чад (рис. 1). Для бассейна Джадо характерно наличие палеозойских пород в основании структуры. Общая мощность чехла достигает примерно 2000 м, но большая часть её приходится на отложения мелового-третичного периодов мощностью до 1200 м [32]. В целом Чадская синеклиза представляет относительно пологую структуру, осложнённую отдельными понижениями и повышениями мощности осадочного чехла в пределах отдельных суббассейнов. На югозападном фланге Чадской синеклизы расположен бассейн Борно, выполненный осадочными породами мелового-третичного возрастов $[12,31]$. Сводных структурных карт изопахит для Чадской синеклизы не имеется, а все прогнозные построения ограничиваются отдельными схематическими геологическими разрезами по буровым и геофизическим данным на участках поисков углеводородов в собственно бассейне озера Чад.

Бассейн Мурзук на территории исследований представляет часть большого одноименного бассейна, расположенного на юге Ливии и сложенного осадочными и терригенными породами с возрастами от кайнозоя до палеозоя [19]. Сводных структурных карт изопахит для южной части бассейна не имеется и все прогнозные построения основаны на геофизических данных по отдельным участкам поисков углеводородов. 
Северо-западная ветвь Чадской синеклизы - система локальных грабенов Центрально-Африканской рифтовой системы (рис. 1) простирается в субмеридиональном направлении почти на 1000 км при ширине до 400 км. Осадочные породы системы грабенов представлены континентальными и морскими отложениями от палеозойского до раннетретичного возраста, с максимальной мощностью до 14 км [23, 29, 31]. Грабены Тенере, Грейн, Кафра, Билма и грабен Термит с его юго-западным продолжением - бассейном Нгуэль Эджи (рис. 1) изучены отдельными глубокими скважинами глубиной до 4500 м, нацеленными на поиски углеводородов. По результатам сейсмических исследований 2D ОГТ для ряда профилей, пересекающих некоторые из указанных грабенов, составлены сводные разрезы осадочного чехла с выделением обобщённых комплексов отложений палеозоя, мезозоя и кайнозоя [20, 23, 33-38]. Мощности выделенных комплексов достигают нескольких тысяч метров, причём наибольшей мощностью (до 7000 м) характеризуются отложения мезозоя.

Приведённые краткие геологические сведения по региону использовались далее при создании модели осадочного чехла территории Республики Нигер и прилегающих стран.

\section{Плотностная модель осадочного чехла}

Для создания структурной схемы мощности слоёв осадочного чехла использовались обобщённые данные цифровых моделей $[13,14]$, охватывающих весь регион исследований. Различие указанных моделей заключается в том, что для модели CRUST1 приведены данные о суммарной мощности осадков, а для модели LITHO1 использована более детальная трёхслойная модель с результатами оценок плотности и скорости осадочных пород, полученными в рамках решения 3D задачи сейсмотомографии по поверхностным волнам. Пространственная детализация указанных цифровых моделей, составляющая 1 градус, отражает основные региональные особенности строения чехла (рис. 2).

Для расчёта аномального гравитационного эффекта от моделей осадочного чехла использовались авторские программы, основанные на адаптивной аппроксимации элементов слоистой модели среды правильными параллелепипедами с градиентом плотности по вертикали $[39,40]$. При расчётах плотность пород в модели CRUST1 принималась постоянной по латерали и равной средневзвешенной плотности осадочного чехла

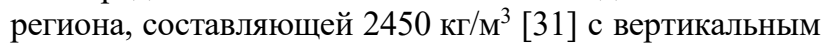
градиентом плотности +5 кг $/ \mathrm{M}^{3}$ км [41], а для модели LITHO1 использовались данные о плотности слоёв непосредственно самой цифровой модели [14]. Для корректного вычисления гравитационного эффекта от пород чехла область задания исходной цифровой плотностной модели бралась с расширением во все стороны в плане на 400 км, что обеспечивало достаточную точность вычисления гравитационных аномалий в результативной области (см. рис. 1).

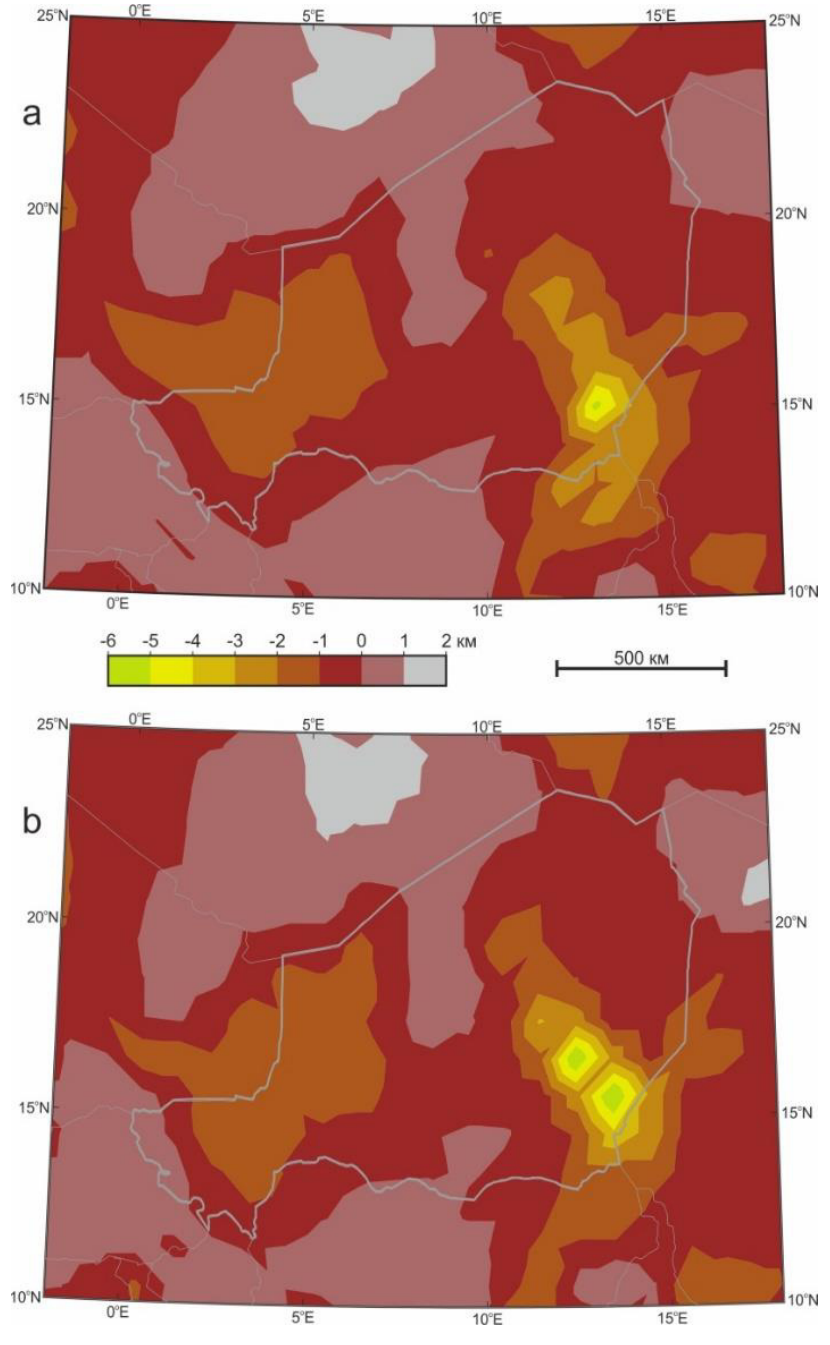

Рис. 2. Глубина подошвы осадочного чехла: $(a)$ модель LITHO1 [14]; (b) модель CRUST1 [13]. Схемы приведены в единой цветовой шкале.

[Fig. 2. Depth of the sedimentary cover bottom: (a) LITHO1 model [14]; (b) CRUST1 model [13]. Schemes are given in a single colour scale.]

Расчёт гравитационного эффекта чехла для моделей CRUST1 и LITHO1, выполненный для всей территории исследований с регулярным шагом на сетке 25 на 25 км показал, что аномалии поля от моделей осадочного чехла хорошо согласуются с региональным структурным планом мощности осадков, но несколько различаются между собой на отдельных участках. Различие полей, представленное в виде гистограммы разности аномальных значений от моделей (рис. 3), демонстрирует хорошее согласие моделей по плотности, но детали строения моделей (см. рис. 2) не отражают особенностей чехла в области рифтовых структур Западно-Африканской рифтовой системы (рис. 1). Отметим, что именно здесь наиболее выражены различия аномальных полей чехла используемых моделей, достигающие первых десятков миллигал. Таким образом, существующие модели чехла [13, 14] требуют существенного уточнения в области Западно-Африканской рифтовой системы. 


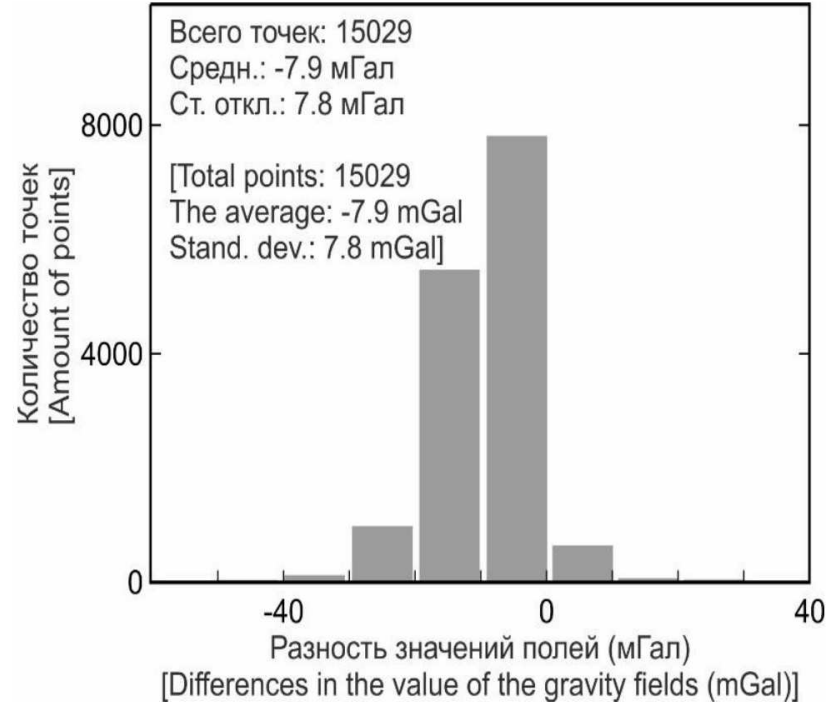

Рис. 3. Гистограмма разности аномалий гравитационного поля осадочного чехла ( $\left.\Delta g_{\text {LITHо }}-\Delta g_{\text {CRUST }}\right)$ от моделей LITHO1 [14] и CRUST1 [13] для области расчётов, показанной на рис. 2.

[Fig. 3. A histogram of the difference between the anomalies of the gravitational field of the sedimentary cover and the LITHO1 [14] and CRUST1 [13] models for the area of calculations shown in the Fig. 2.]

При последующих построениях, в качестве региональной цифровой модели чехла была взята верхняя часть модели LITHO1, которая имеет трёхслойное строение с оценками величин плотности в слоях. Улучшение модели чехла выполнялось только в области Западно-Африканской рифтовой системы, для которой имеются достоверные сейсмические данные 2D OГТ по строению осадочного комплекса [17-20 и др.]. Схема мощности осадочного чехла, приведённая в [20], была привязана к географическим координатам изучаемой территории в геоинформационной системе ArcView и векторизована в цифровую карту глубин до кристаллического фундамента с учётом значений высот рельефа в точках векторизации [42]. По сейсмическим данным [17-20, 23, 33-38] в осадочном чехле территории выявляются три основных структурных этажа, сложенных породами кайнозоя, мезозоя и палеозоя. Мощности этих толщ определены только на отдельных профилях и не всегда прослеживались до фундамента. Поэтому, детализация цифровой модели чехла потребовала привлечения, помимо сейсмических данных, ряда геологических материалов, рассматривающих интенсивность накопления осадочных пород в палеозойских интракратонных бассейнах северной Гондваны [19]. Приводимые автором многочисленные данные, по району бассейна Хоггар, расположенному в южной части Алжира, совместно с данными результатам сейсмических построений 2D ОГТ по Западно-Африканской рифтовой системе, позволили предложить простые соотношения, связывающие общую мощность чехла и мощности его основных структурных комплексов, приведённые в таблице 1.
Табл. 1. Соотношение мощностей

структурных комплексов чехла

[Table 1. The ratio of the thicknesses of the structural complexes of the cover]

\begin{tabular}{|c|c|c|c|}
\hline $\begin{array}{c}\text { Мощность чехла, км } \\
\text { [Cover thickness, } \mathrm{km}]\end{array}$ & $\mathrm{Kz}, \%$ & $\mathrm{Mz}, \%$ & $\mathrm{Pz}, \%$ \\
\hline$<1.5$ & 66.6 & 33.3 & 0 \\
$1.5-3$ & 60 & 35 & 5 \\
$3-6$ & 50 & 40 & 10 \\
$6-10$ & 40 & 40 & 20 \\
$10-12$ & 33 & 42 & 25 \\
$>12$ & 27.5 & 45 & 27.5 \\
\hline
\end{tabular}

На основании предложенного обобщения был выполнен переход от суммарной мощности осадков к мощностям отдельных структурных ярусов, которые в нашей цифровой модели далее преобразовывались в глубинное положение границ кровли и подошвы слоёв модели осадочного чехла для всей территории исследований. Фрагмент сводной схемы глубин подошвы слоёв чехла, составленный из данных модели LITHO1, на внешности области Западно-Африканской рифтовой системы, и векторизованных сейсмических данных из [20] внутри этой области, показан на рис. 4. В рамках нашей модельной области диапазоны мощности отдельных комплексов чехла и их средние значения составляют: для кайнозойских пород 0.0-4.3 км (среднее $1.52 \mathrm{kм}$ ), для мезозойских пород 0.0-6.1 км (среднее 1.02 км), для палеозойских пород 0.0-4.9 км (среднее 0.24 км). Столь малая величина средней мощности палеозойского комплекса говорит о том, что в модели LITHO1 практически отсутствует третий слой чехла, который, тем не менее, представлен в сейсмических данных из [17-20, 23, 33-38].

Помимо данных о положении границ слоёв при создании цифровой петрофизической модели чехла использовались сведения о плотности осадочных пород региона, установленные по результатам гаммагамма плотностного каротажа глубоких скважин бассейна Иуллеммеден и грабенов Термит, Тефидет, Тенере [31, 43-48]. Поскольку указанные данные о плотности затрагивают лишь верхнюю часть разреза (кайнозой и частично мезозой), то для обобщённого представления плотности пород в области развития грабенов Западно-Африканской рифтовой системы (см. рис. 1) был выполнен анализ плотностных колонок по имеющимся скважинам. Результаты такого анализа позволили предложить простые линейные соотношения зависимости плотности осадков от глубины их залегания в форме

$$
\sigma(z)=\sigma_{0}+a * z,
$$

где $\sigma_{0}-$ значение плотности пород при отсутствии литостатической нагрузки (кг/м $\left.\mathbf{M}^{3}\right), \mathrm{z}$ - мощность вышележащих пород (км), $a$ - вертикальный градиент плотно-

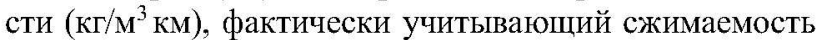
осадочных пород, согласно $[1,11,12]$. Отметим, что для глубоких горизонтов чехла, где данные о плотности брались из данных модели LITHO1, принимались во внимание сведения о плотности палеозойских 

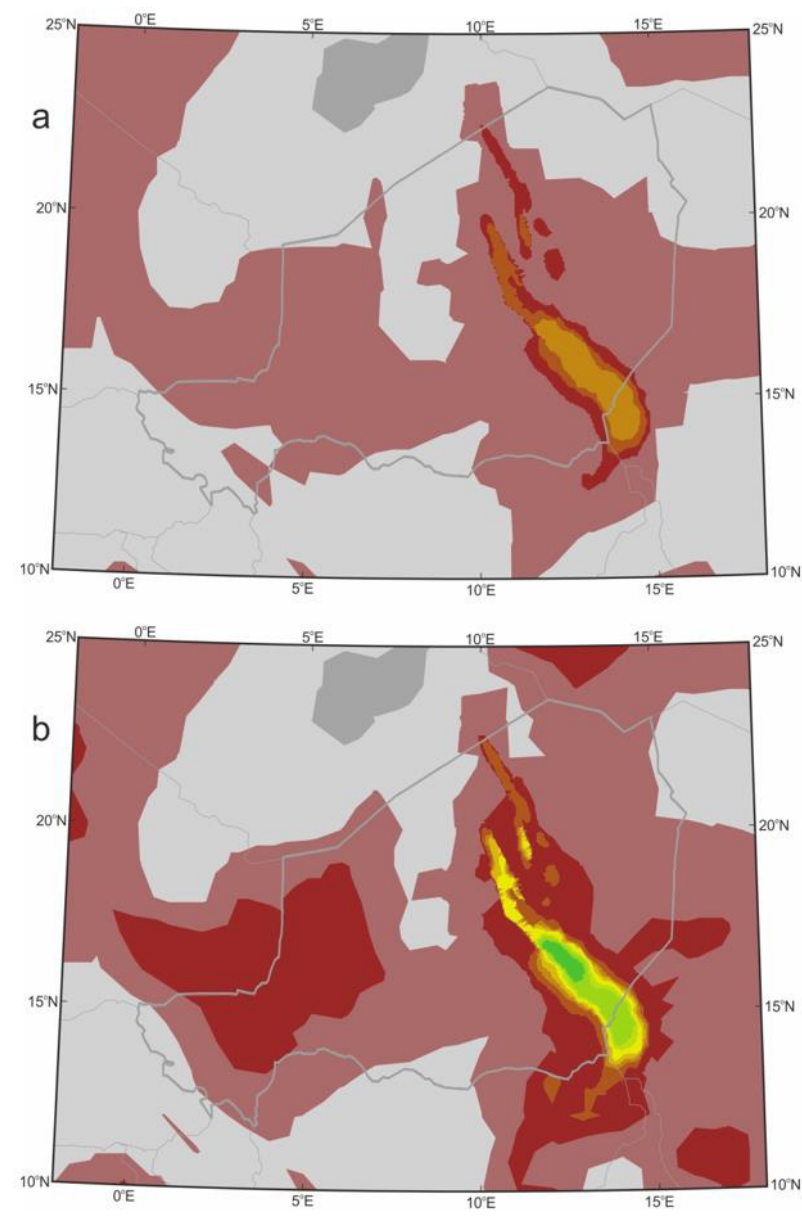

пород, аналогичного литологического состава, установленных для глубоких впадин ВосточноЕвропейской платформы и Баренцевоморской плиты [49-51]. Обобщённые данные для коэффициентов, используемых в соотношении (1), представлены в таблице 2.

Табл. 2. Коэффициенты зависимости плотности от глубины

[Table 2. Coefficients of dependence of density on depth]

\begin{tabular}{|c|c|c|}
\hline $\begin{array}{l}\text { Комплекс чехла } \\
\text { [Cover complex] }\end{array}$ & $\sigma_{0}, \kappa \Gamma / \mathbf{M}^{3}$ & $a, \mathrm{\kappa} \Gamma / \mathrm{M}^{3} \mathrm{\kappa M}$ \\
\hline кайнозойский & 2000 & 97,5 \\
\hline мезозойский & 2370 & 26,3 \\
\hline палеозойский & 2550 & 13,2 \\
\hline
\end{tabular}

На основе аппроксимационных данных о плотности пород в слоях осадочного чехла (табл. 2) и глубинах залегания границ комплексов (рис. 4) была составлена сводная цифровая модель строения осадочного чехла по всему региону исследований и его обрамлению. Сводная модель включает региональные данные о чехле, содержащиеся в модели LITHO1, и более детальные данные, сформированные на основе сейсмических данных 2D ОГТ и петроплотностных исследований по глубоким скважинам, в области развития грабенов Западно-Африканской рифтовой системы на территории Республики Нигер. Плотность

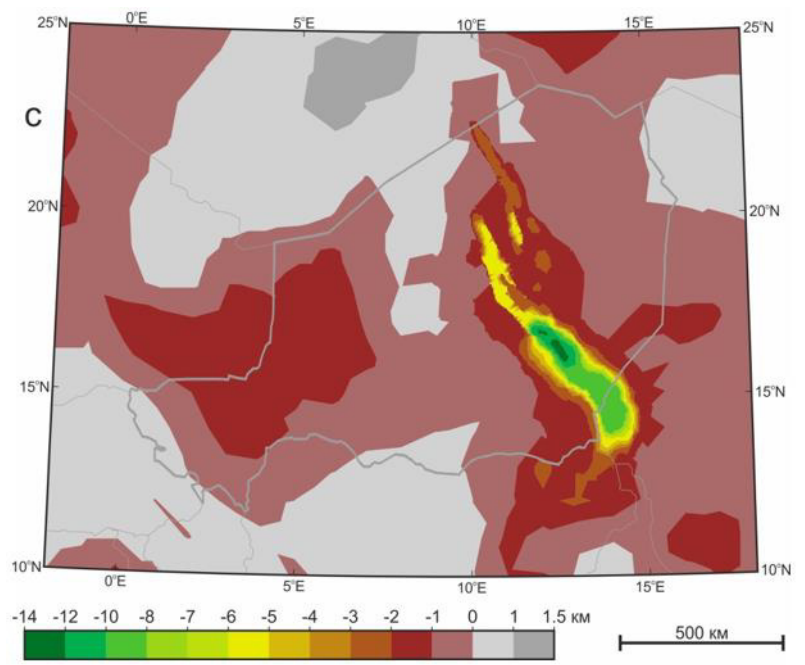

Рис. 4. Сводная модель осадочного чехла по данным LITHO1 [14] и результатам 2D ОГТ: (a) подошва слоя $1 ;(b)$ подошва слоя 2; (c) подошва слоя 3. Схемы приведены в единой цветовой шкале.

[Fig. 4. Overall model of sedimentary cover according to LITHO1 data [14] and 2D CDP results: $(a)$ bottom of the layer $1 ;(b)$ bottom of the layer 2; (c) bottom of the layer 3. Schemes are given in a single colour scale.]

слоёв чехла в сводной модели изменяется по латерали и вертикали в диапазонах: 1860-2415 кг/м $\mathrm{M}^{3}$ (среднее

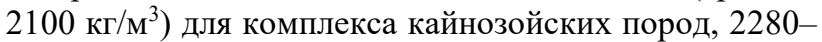
2640 кг $/ \mathrm{M}^{3}$ (среднее 2416 кг $/ \mathrm{M}^{3}$ ) для мезозойских пород

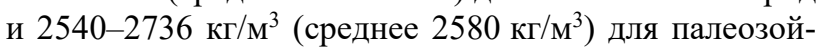
ских пород. В целом приведённые аппроксимационные данные хорошо согласуются с плотностями осадочных слоёв в модели LITHO1.

\section{Гравитационный эффект осадочного чехла}

На следующем этапе сводная цифровая модель чехла была интерполирована в регулярную правильную сетку с плановым шагом 10 на 10 км. Интерполяция выполнялась для региона исследований (см. рис. 1) и его обрамления на дистанции примерно 400 км. Полученная 3D цифровая модель, содержащая положение границ и значение плотностей на кровле и подошве слоёв, использовалась для расчёта гравитационного эффекта осадочного чехла территории исследований. Программа решения прямой задачи основана на адаптивной аппроксимации элементов слоистой модели среды правильными параллелепипедами с градиентом плотности по вертикали $[39,40]$. Расчёт поля от модели осадочного чехла выполнялся в точках регулярной сети 5 на 5 км на реальном рельефе региона [42]. В качестве нормальной плотностной модели и её поля относимости использовалась модель К. М. Картвелишвили ПМЗ-К 
[52], взятая для верхнего слоя модели коры: мощность 20 км и плотность 2720 кг/м³ . Вычисленный аномальный гравитационный эффект сводной цифровой модели осадочного чехла приведён на рис. 5.

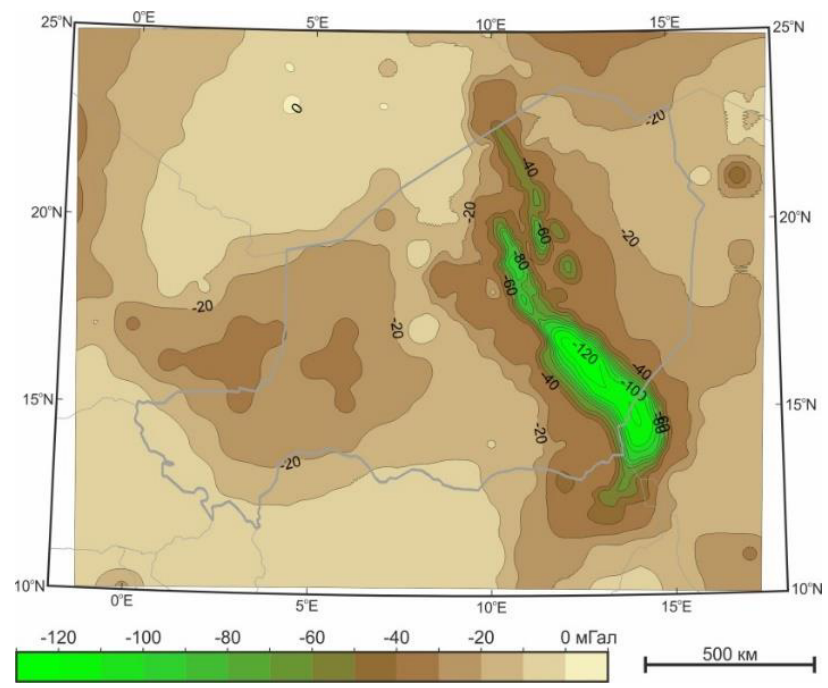

Рис. 5. Рассчитанный гравитационный эффект осадочного чехла.

[Fig. 5. Calculated gravitational effect of the sediment cover.]

Главным морфологическим элементом рассчитанного поля чехла является выраженная субмеридиональная область, отвечающая положению зоны развития грабенов Западно-Африканской рифтовой системы на территории Республики Нигер, Чада и Нигерии (см. рис. 1). Амплитуды аномалий в этой локальной области достигает -125 мГал и чётко соответствует наиболее глубокой части рифтовой системы, в частности грабену Термит, где суммарная мощность осадков составляет почти 16 км (см. рис. 4). Грабены Тенере, Кафра и Грейн (см. рис. 1) в аномальном гравитационном поле выражены слабее и гравитационные аномалии от осадочного чехла достигают только немногим менее -60 мГал, что обусловлено меньшими плановыми размерами этих геологических структур и общей уменьшенной мощностью пород чехла. Локальные изометричные структурные элементы Западно-Африканской рифтовой системы, представленные бассейнами Джадо, Агадема и Нгуэль Элжи (см. рис. 1), отмечаются понижением уровня поля примерно на 5-10 мГал по сравнению с соседними областями. Локальный бассейн Билма (см. рис. 1) выражен более чётко с понижением уровня поля, по сравнению с прилегающими областями, на 20-25 мГал. Бассейн Борно, представляющий вытянутую в юго-западном направлении относительно узкую структуру чехла, связывающую Центрально-Африканскую и ЗападноАфриканскую рифтовые системы (см. рис. 1), выражен слабо-градиентной аномалией, такой же ориентировки, с понижением уровня поля на 15-25 мГал.

Крупные синеклизы и региональные осадочные бассейны достоверно отражены в аномальном грави- тационном поле, обусловленном нашей моделью чехла. Мали-Нигерская синеклиза и её западное продолжение (см. рис. 1) характеризуется пологими изометричными региональными аномалиями гравитационного поля с амплитудой до -30 мГал (рис. 5). Минимальные значения аномалий коррелируются с областями повышения общей мощности осадочного чехла в пределах синеклизы (см. рис. 4), причём в аномальном поле отражается и латеральные вариации плотности пород чехла, проявляющиеся в наличии двух обособленных минимумов поля в центральной части Мали-Нигерской синеклизы. Линейная структура аномального поля северо-западного простирания, разделяющая области относительного повышения поля, отвечающим щитам Туарег и Леоман (см. рис. 1), приближённо совпадает с областью максимальной мощности чехла в южной части бассейна Иуллеммеден.

Чадская синеклиза, имеющая весьма пологие борта и общее погружение в юго-восточном направлении (см. рис. 4), в региональном гравитационном поле проявляется понижением уровня на 15-25 мГал по сравнению с соседними областями (рис. 5) вне зоны Западно-Африканской рифтовой системы. Отметим также выраженное восточное и северовосточное продолжение аномальной области поля Чадской синеклизы, имеющее аналогичные амплитуды, но более локальные формы аномалий (рис. 5). Расположенный в северо-восточной части региона южный фрагмент бассейна Мурзук соответствует понижению аномального поля до -30 мГал (рис. 5), а за пределами нашего региона исследований эта аномалия ещё более уменьшается по амплитуде.

\section{Заключение}

По результатам обобщения региональных сейсмотомографических данных (модель LITHO1) и новых детальных профильных данных сейсморазведки 2D ОГТ, а также данных определения плотности осадочных пород по глубоким скважинам региона, составлена сводная цифровая модель осадочного чехла территории Республики Нигер и рассчитано поле гравитационных аномалий, обусловленных этой моделью. Выполненные расчёты поля позволят в дальнейшем обратиться к учёту вклада аномалий от осадочного чехла в суммарное наблюдённое поле региона и определение аномального гравитационного поля кристаллической коры, задача интерпретации которого представляет отдельную вычислительную проблему.

Конфликт интересов: Авторы декларируют отсутствие явных и потенциальных конфликтов интересов, связанных с публикацией настоящей статьи.

\section{ЛИТЕРАТУРА}

1. Глазнев В.Н. Комплексные геофизические модели литосферы Фенноскандии. Апатиты, «КаэМ». 2003. 252 с.

2. Муравина О. М. Плотностная модель земной коры Воронежского кристаллического массива // Вестник Воронежского государственного университета. Серия: Геология. 2016. № 1. С. 108-114. 
3. Mints M. V., Glaznev V. N., Muravina O. M., Sokolova E. Yu. 3D model of Svecofennian Accretionary Orogen and Karelia Craton based on geology, reflection seismics, magnetotellurics and density modelling: Geodynamic speculations // Geoscience Frontiers. 2020. Vol. 11. № 3. P. 999-1023. DOI: 10.1016/j.gsf.2019.10.003

4. Чекунов А. В., Старостенко В. И., Красовский С. С., Кутас Р. И., Оровецкий Ю. П., Пашкевич И. К., Трипольский А. А., Елисеева С. В., Куприенко П. Я., Митрофанов Ф. П., Шаров Н. В., Загородный В. Г., Глазнев В. Н., Гарецкий Р. Г., Каратаев Г. И., Аксаментова Н. В., Гутерх А., Грабовска Т., Кобланьски А., Рыка В., Дадлез Р., Цвойдзински С., Корхонен Х., $\quad$ Луосто У., Журавлев В. А., Садов А. С. Геотрансект Евро-3 // Геофизический журнал. 1993. Т. 15. № 2. С. 3-32.

5. Glaznev V. N., Raevsky A. B., Skopenko G. B. A threedimensional integrated density and thermal model of the Fennoscandian lithosphere // Tectonophysics. 1996. Vol. 258. №1-4. P. 15-33. DOI: 10.1016/0040-1951(95)00147-6

6. Glaznev V. N., Mints M. V., Muravina O. M., Raevsky A. B., Osipenko L. G. Complex geological-geophysical 3D model of the crust in the southeastern Fennoscandian Shield: Nature of density layering of the crust and crust-mantle boundary // Geodynamics \& Tectonophysics. 2015. Vol. 6. №2. P. 133170. DOI: $10.5800 /$ GT-2015-6-2-0176

7. Глазнев В. Н., Минц М. В., Муравина О. М. Плотностное моделирование земной коры центральной части Восточно-Европейской платформы // Вестник КРАУНЦ. Сер.: Науки о Земле. 2016. №1(29). С. 53-63.

8. Mitrofanov F. P., Sharov N. V., Zagorodny V. G., Glaznev V. N., Korja A. Crustal structure of the Baltic shield along the Pechenga - Kostomuksha - Lovisa geotraverse // International Geology Review. 1998. V. 40. №11. P. 990-997. DOI: 10.1080/0020681980946

9. Глазнев В. Н., Жаворонкин В. И., Минц М. В., Муравина О. М., Хованский Н. Е. Петроплотностная модель и гравитационный эффект осадочного чехла Воронежского кристаллического массива и его обрамления. Материалы 40-ой сессии международного семинара им. Д.Г. Успенского «Вопросы теории и практики геологической интерпретачии геофизических полей». М.: ИФЗ РАН, 2013. С. 107-112.

10. Минц М. В., Глазнев В. Н., Муравина О. М. Глубинное строение коры юго-востока Воронежского кристаллического массива по геофизическим данным: геодинамическая эволюция в палеопротерозое и современное состояние коры // Вестник Воронежского государственного университета. Серия: Геология. 2017. № 4. С. 5-23.

11. Муравина О. М., Жаворонкин В. И., Глазнев В. Н. Петрофизическая характеристика осадочного чехла Воронежской антеклизы // Вестник Воронежского государственного университета. Серия: Геология. 2013. №1. С. 189-196.

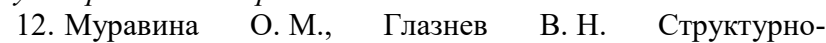
параметрические модели петрофизических параметров осадочного чехла Воронежской антеклизы // Известия CO PAEH. 2014. T. 44. № 1. C. 81-87.

13. Laske G., Masters G., Ma Z., Pasyanos M. Update on CRUST1.0 - A 1-degree Global Model of Earth's Crust // Abstract EGU2013-2658 presented at 2013 Geophys. Res. Abstracts. 2013. 15. EGU2013-2658.

14. Pasyanos M. E., Masters G., Laske G., Ma Z. LITHO1.0 : An updated crust and lithospheric model of the Earth // Journal Geophysical Research. Solid Earth. 2014. Vol. 119. P. 21532173. DOI: $10.1002 / 2013$ JB010626

15. Глазнев В. Н., Якуба И. А. Мощность земной коры территории Республики Нигер по данным стохастической интерпретации гравитационного поля // Вестник Воронежс- кого государственного университета. Серия: Геология. 2020. №4. C. 46-58. DOI: 10.17308/geology.2020.4/3126

16. Yacouba I. A., Glaznev V. N. The thickness of the Earth's crust in the territory of Republic of the Niger according to the stochastic interpretation of the gravity field. In: Kukkonen I.T., Veikkolainen T., Heinonen S., Karell F., Kozlovskaya E., Luttinen A., Nikkilä K., Nykänen V., Poutanen M., Skyttä P., Tanskanen E. and Tiira T. (Eds.). 2021. Lithosphere 2021 - Eleventh Symposium on the Structure, Composition and Evolution of the Lithosphere in Finland. Programme and Extended Abstracts, January 19-20, 2021. Institute of Seismology, University of Helsinki. Report S-71. P. 157-160.

17. Brownfield M. E. Assessment of undiscovered oil and gas resources of the Chad Basin Province, north-central Africa. In Brownfield M.E. (Ed.) Geologic assessment of undiscovered hydrocarbon resources of Sub-Saharan Africa. 2016. U.S. Geological Survey Digital Data Series 69-GG. Chap. 6. 9 p. DOI: $10.3133 / \mathrm{ds} 69 \mathrm{GG}$

18. Lihong Z., Junqing S., Xiaowei D., Buqing S., Zhihua S., Maolu Q., Da L., Aiping L. Controlling factors of hydrocarbon accumulation in Termit rift superimposed basin, Niger // Petroleum Exploration and Development. 2017. Vol. 44. №. 3. P. 358-367. DOI: 10.1016/S1876-3804(17)30042-3

19. Perron P. Architecture and tectonic of Paleozoic intracratonic Basins : impact on the sedimentary record and associated geometries : example of peri-Hoggar Basins (North Gondwana marge). These de Doctorat. Université Bourgogne FrancheComté. 2019. 394 p. NNT: 2019UBFCK022-tel-02284343

20. Ahmed K. S., Liu K., Paterne M. A., Kra K.L., Kuttin A. A.A., Malquaire K.P.R., Ngum K.M.M.-A. Anatomy of Eastern Niger Rift Basin with Specific References of Its Petroleum Systems // International Journal of Geosciences. 2020. Vol. 11. № 5. P. 305-324. DOI: 10.4236/ijg.2020.115016

21. Jessell M. W., Begg G. C., Miller M. S. The Geophysical Signatures of the West African Craton // Precambrian Research. 2016. Vol. 274. № 3. P. 3-24. DOI: 10.1016/j.precamres.2015.08.010

22. Guiraud R., Maurin J.C. Early Cretaceous rifts of Western and Central Africa: an overview // Tectonophysics. 1992. Vol. 213. P. 153-168. DOI: 10.1016/0040-1951(92)90256-6

23. Genik G. J. Regional framework, structural and petroleum aspects of rift basins in Niger, Chad and the Central African Republic // Tectonophysics. 1992. Vol. 213. P. 169-185. DOI: 10.1016/0040-1951(92)90257-7

24. Greigert J. Description des formations cretacés et tertiaires $\mathrm{du}$ bassin des Iullemenden (Afrique occidentale). Ministere des Travaux publics, des Transports, des Mines et de l'Urbanisme de la republique du Niger. Direction des mines et de la geologie, 2. Paris, France. BRGM. 1966. 229 p.

25. Greigert J., Pougnet R. Notice explicative sur la carte geologique de la Republique du Niger à l'echelle du $1: 2$ 000000 . Ministere de Travaux publics, des Transports, des Mines et de l'Urbanisme de la republique du Niger. Paris, France. BRGM. 1967-a. 62 p.

26. Greigert J., Pougnet R. Essai de description des formations geologiques de la republique du Niger. Ministere des Travaux publics, des Transports, des Mines et de l'Urbanisme de la republique du Niger. Direction des mines et de la geologie, 3. Paris, France. BRGM. 1967-b. 267 p.

27. Clermonté J., Yahaya M., Lang J., Oumarou J. Un bassin paléozoïque et mésozoïque en décrochement : le Tim Mersoï dans la région d'Arlit, à l'Ouest de l'Aïr (Niger) // Comptes rendus de l'Académie des sciences. Série 2. 1991. Vol. 312. P. 1189-1195.

28. Gaoh D. A. Etude des nappes aquiferes du Contiental Terminal entre les Dallols Bosso et Maouri, departement de 
Dosso, republique du Niger. Université de Liege, Belgique. These sciences. 1993. 258 p.

29. BGR \& ABN. Geological map of transboundary region of Benin, Niger and Nigeria: Sedimentary basins Iullemenden, Kandi, Sokoto. Berlin \& Niamey. 2019.

30. Avbovbo A., Ayoola E., Osahon G. Depositional and Structural Styles in Chad Basin of Northeastern Nigeria // AAPG Bulletin. $\quad 1986 . \quad$ Vol. 70. P. 1787-1798. DOI: 10.1306/94886D21-1704-11D7-8645000102C1865D

31. Genik G. J. Petroleum Geology of Rift Basins in Niger, Chad, and Central African Republic // AAPG Bulletin. 1993. Vol. 77. P. 1405-1434. DOI: 10.1306/BDFF8EAC-1718-11D7$8645000102 \mathrm{C} 1865 \mathrm{D}$

32. Greigert J. Les eaux souterraines de la republique du Niger/ Ministere des Travaux Publics, des Transports, des Mines et de l'Urbainisme de la republique du Niger. Rapport BRGM. Niamey, Niger. 1968. ABI 006 NIA. 2 volumes, 407 p.

33. Fairhead J.D. Geophysical Controls on Sedimentation within the African Rift Systems. In: Frostick L.E., Renaut R.W., et al., Eds. Sedimentation in the African Rifts // Geological Society, London, Special Publications. 1986. Vol. 25. P. 19-27. DOI: 10.1144/GSL.SP.1986.025.01.03

34. Bellion Y. Histoire geodynamique post-paleozoique de l'Afrique de l'Ouest d'apres l'etude de quelques bassins sedimentaires (Senegal, Taoudeni, IUllemenden, Tchad). Centre International pour la formation et les echanges Geologiques. CIFEG. 1987. Vol. 17. 302 p.

35. Fairhead J. D., Green C.M. Controls on Rifting in Africa and the Regional Tectonic Model for the Nigeria and East Niger Rift Basins // Journal of African Earth Sciences. 1989. Vol. 8. P. 231-249. DOI: 10.1016/S0899-5362(89)80027-2

36. Zanguina M., Bruneton A., Gonnard R. An introduction to the petroleum potential of Niger // Journal Petroleum Geology. 1998. Vol. 21. № 1. P. 83-103. DOI: 10.1111/j.17475457.1998.tb00647.x

37. Davidson L., Beswetherick S., Craig J., Eales M., Fisher A., Himmali A., Jho J., Mejrab B., Smart J. The structure, stratigraphy and petroleum geology of the Murzuq Basin, southwest Libya. In: D. Worsley, M.A. Sola (Eds.). Geological Exploration in the Murzuq Basin. Elsevier Science. 2000. P. 295-320. DOI: $10.1134 / \mathrm{S} 0016702914060032$

38. Liu B., Wan L.K., Mao F.J., Liu, J., Lu M.S., Wang Y. Hydrocarbon Potential of Upper Cretaceous Marine Source Rocks in the Termit Basin, Niger // Journal of Petroleum Geology. 2015. Vol. 38. P. 157-175. DOI: 10.1111/jpg.12604

39. Глазнев В. Н., Лошаков Г. Г. Об одном методе моделирования рудных объектов с использованием адаптивной аппроксимации // Вестник Воронежского государственного университета. Серия: Геология. 2012. № 1. С. 243-246.

40. Муравина О.М., Лошаков Г. Г. Принципы решения прямых задач потенциала при моделировании строения литосферы // Вестник Воронежского государственного университета. Серия: Геология. 2015. № 3. С. 97-100.
41. Nguimbous-Kouoh J. J., Ndougsa-Mbarga T., NjandjockNouck P., Eyike A., Campos-Enriquez J.O., Manguelle-Dicoum E. The structure of the Goulfey-Tourba sedimentary basin (Chad-Cameroon): a gravity study // Geofisica Internacional. 2010. Vol. 49. №4. P. 181-193. DOI: 10.22201/igeof.00167169p.2010.49.4.127

42. Amante C., Eakins B.W. ETOPO1 - 1 Arc-Minute Global Relief Model: Procedures, Data Sources and Analysis // NOAA Technical Memorandum NESDIS NGDC-24. National Geophysical Data Center, NOAA, 2009. DOI: 10.7289/V5C8276M

43. De Marsily G. Hydrogeologie: comprendre et estimer les ecoulements souterrains et le transport des polluants. Cours de l'ecole des Mines de Paris. France, Paris. 1994. 243 p.

44. Muhammad N.N., Lo S.-Z., Abdul G.M.R. Petrophysical analysis of E5 sand group of Sokor formation, Termit basin, Niger // IOP Conf. Series: Earth and Environmental Science. Vol. 88. N 012003 2017. DOI: 10.1088/1755-1315/88/1/012003 45. Muhammad S.Z.M., Lo S.-Z., Abdul G.M.R. Petrophysical Analysis on Radioactive Sands for Koala Field in Termit Basin, Niger // Journal of Engineering and Applied Sciences. 2018. Vol. 13. № 13. $\quad$ P. 5122-5130. 10.36478/jeasci.2018.5122.5130

46. Li Z., Cheng X., Jiang H., Zheng F. Genetic mechanism of low-resistivity oil zones and comprehensive identification technology for well logging in the Termit Basin. Niger // Science Frontiers. 2018. V. 25. № 2. P. 099-111. DOI: 10.13745/j.esf.2018.02.011

47. Ning Z., Xia G., Jiangqin H., Zhongmin C., Guangya Z. Sedimentary characteristics and lithological trap identification of Distant Braided delta deposits: a case on upper Cretaceous Yogou formation of Termit Basin, Niger. $3^{\text {rd }}$ International Conference on Advances in Energy and Environment Research. Abstracts. 2018. Vol. 53. DOI: 10.1051/e3sconf/20185303020 48. Lai H., Li M., Mao F., Liu J., Xiao H., Tang Y., Shi S. Source rock types, distribution and their hydrocarbon generative potential within the Paleogene Sokor-1 and LV formations in Termit Basin, Niger // Energy Exploration \& Exploitation. 2020. Vol. 38 (6). P. 2143-2168. DOI: 10.1177/0144598720915534 49. Galitchanina L. D., Glaznev V. N., Mitrofanov F. P., Olesen O., Henkel H. Surface density characteristics of the Baltic Shield and adjacent territories // Norges Geologiske Undersokelse. 1995. Special Publ. Vol. 7. P. 349-354.

50. Шипилов Э. В., Тюремнов В. А., Глазнев В. Н., Голубев В. А. Палеогеографические обстановки и тектонические деформации Баренцевоморской континентальной окраины в кайнозое // Доклады АН. 2006. Т. 407. № 3. С. 378-383.

51. Муравина О. М. Идентификационный анализ петрофизических характеристик пород осадочного чехла Воронежской антеклизы // Вестник КРАУНЦ. Сер.: Науки о Земле. 2013. № 2 (22). С. 20-25.

52. Картвелишвили К. М. Планетарная плотностная модель и нормальное гравитационное поле Земли. М.: Наука. 1983. $93 \mathrm{c}$. 


\title{
The gravitational effect of the sedimentary cover located in the Republic of Niger
}

\author{
(c) 2020 V. N. Glaznev ${ }^{1,2}$, I. A. Yacouba ${ }^{1 凶}$ \\ ${ }^{1}$ Voronezh State University, 1 Universitetskaya pl., \\ Voronezh 394018, Russian Federation \\ ${ }^{2}$ Geological Institute of the Kola Science Centre of the Russian Academy of Sciences, 14 Fersmana ul., \\ Apatity 184209, Russian Federation
}

\begin{abstract}
Introduction: The article considers the approaches and results of creating a conceptual geological model of the sedimentary cover in the Republic of Niger and its framing to be used to calculate the gravitational effect of the sedimentary cover in the studied area. The anomalous field of the cover is necessary to reduce the observed gravitational field due to density heterogeneities in the sedimentary cover.

The structure of the sedimentary cover in the region: The study considered the main features of the structure of the sedimentary cover located in the Republic of Niger. It also described the lithological composition and thicknesses of major structural levels of the cover for syneclises, basins, and grabens in the West African Rift System. The provided data were used to create a model of the sedimentary cover in the Republic of Niger and the neighbouring countries.

Density model of the sedimentary cover: The overall density model of the cover includes regional data on the density of sedimentary rocks contained in the LITHO1 model and detailed data generated by using 2D CDP seismic data and the data of petrodensity research in the deep wells of the region. Density characteristic of sedimentary rock layers was provided in the overall model of the cover.

The gravitational effect of the sedimentary cover: The anomalous gravitational effect of the overall digital model of the sedimentary cover was calculated and a generalised morphological characteristic of the field anomalies was provided. The features of the field anomalies in the area of graben development in the West African Rift System were determined.

Conclusions: The main results of the study were formulated and the tasks regarding the calculation of the anomalous gravitational field generated by sources in the crystalline crust were outlined.
\end{abstract}

Keywords: The Republic of Niger, sedimentary cover, gravitational field of the cover

For citation: Glaznev V. N., Yacouba I. A. The gravitational effect of the sedimentary cover located in the Republic of Niger. Vestnik Voronezhskogo gosudarstvennogo universiteta. Seriya: Geologiya - Proceedings of Voronezh State University. Series: Geology, 2021, no. 2, pp. 71-82.

DOI: https://doi.org/10.17308/geology.2021.2/3490

Conflict of interests: The authors declare the absence of obvious and potential conflicts of interest related to the publication of this article.

\footnotetext{
\Ibrahim Abdou Yacouba, e-mail: yibrahimabdou@yahoo.fr
} 


\section{REFERENCES}

1. Glaznev V. N. Kompleksnye geofizicheskie modeli litosfery Fennoskandii [Complex geophysical models of the lithosphere of Fennoscandia]. Apatity, «KaeM» publ., 2003. 252 p. (In Russ.)

2. Muravina O. M. Plotnostnaya model' zemnoi kory Voronezhskogo kristallicheskogo massiva [Density model of the Earth's crust of the Voronezh crystalline massif]. Vestnik Voronezhskogo gosudarstvennogo universiteta. Seriya: Geologiya - Proceedings of Voronezh State University. Series: Geology, 2016, no. 1, pp. 108-114. (In Russ.) 3. Mints M. V., Glaznev V. N., Muravina O. M., Sokolova E. Yu. 3D model of Svecofennian Accretionary Orogen and Karelia Craton based on geology, reflection seismics, magnetotellurics and density modelling: Geodynamic speculations. Geoscience Frontiers, 2020, vol. 11, no. 3, pp. 999-1023. DOI: 10.1016/j.gsf.2019.10.003

4. hekunov A. V., Starostenko V. I., Krasovskii S.S., Kutas R. I., Orovetskii Yu. P., Pashkevich I. K., Tripol'skii A. A., Eliseeva S. V., Kuprienko P. Ya., Mitrofanov F. P., Sharov N. V., Zagorodnyi V. G., Glaznev V. N., Garetskii R. G., Karataev G. I., Aksamentova N. V., Guterkh A., Grabovska T., Koblan'ski A., Ryka V., Dadlez R., Tsvoidzinski S., Korkhonen Kh., Luosto U., Gaal G., Zhuravlev V. A., Sadov A. S. Geotransekt Evro-3 [Geotranssect Euro-3]. Geofizicheskii zhurnal - Geophysical journal, 1993, vol. 15, no 2, pp. 3-32. (In Russ.)

5. Glaznev V. N., Raevsky A. B., Skopenko G. B. A threedimensional integrated density and thermal model of the Fennoscandian lithosphere. Tectonophysics, 1996, vol. 258, no. 1-4, pp. 15-33. DOI: 10.1016/0040-1951(95)00147-6

6. Glaznev V. N., Mints M. V., Muravina O. M., Raevsky A. B., Osipenko L. G. Complex geological-geophysical 3D model of the crust in the southeastern Fennoscandian Shield: Nature of density layering of the crust and crust-mantle boundary. Geodynamics \& Tectonophysics, 2015, vol. 6, no. 2, pp. 133-170. DOI: 10.5800/GT2015-6-2-0176

7. Glaznev V. N., Mints M. V., Muravina O. M. Plotnostnoe modelirovanie zemnoy cory chentalnoq tchasti Vostochno-Evropeiskoy platformy [Density modeling of the earth's crust of the central part of the Eastern European platform. Vestnik KRAUNTs. Ser.: Nauki o Zemle - The KRAUNZ Herald. Ser.: Earth Sciences, 2016, no. 1 (29), pp. 53-63. (In Russ.)

8. Mitrofanov F. P., Sharov N. V., Zagorodny V. G., Glaznev V. N., Korja A. Crustal structure of the Baltic shield along the Pechenga - Kostomuksha - Lovisa geotraverse. International Geology Review, 1998, vol. 40, no. 11, pp. 990-997. DOI: $10.1080 / 0020681980946$

9. Glaznev V. N., Zhavoronkin V. I., Mints M. V., Muravina O. M., Khovanskii N. E. Petroplotnostnaya model' i gravitatsionnyi effekt osadochnogo chekhla Voronezhskogo kristallicheskogo massiva i ego obramleniya [Petro-density model and gravitational effect of the sedimentary cover of the Voronezh crystalline massif and its framing.]. Materialy 40-oi sessii mezhdunarodnogo seminara im. D.G. Uspenskogo «Voprosy teorii i praktiki geologicheskoi interpretatsii geofizicheskikh polei» [Materials of the 40th session of the international seminar. D. G. Uspensky "Questions of theory and practice of geological interpretation of geophysical fields."]. Moscow, IFZ RAN, 2013, pp. 107-112. (In Russ.)

10. Mints M. V., Glaznev V. N., Muravina O. M. Deep structure of the southeast Voronezh crystal massif according to geophysical data: geodynamic evolution in the paleoproterozoic and modern state of the crust. Vestnik Voronezhskogo gosudarstvennogo universiteta. Seriya: Geologiya - Proceedings of Voronezh State University. Series: Geology, 2017, no. 4, pp. 5-23. (In Russ.)

11. Muravina O. M., Zhavoronkin V. I., Glaznev V. N. Petrophysical characteristics of the sedimentary cover of the Voronezh anteclise. Vestnik Voronezhskogo gosudarstvennogo universiteta. Seriya: Geologiya - Proceedings of Voronezh State University. Series: Geology, 2013, no. 1, pp.. 189-196. (In Russ.)

12. Muravina O.M., Glaznev V.N. Strukturno-parametricheskie modeli petrofizicheskikh parametrov osadochnogo chekhla Voronezhskoi anteklizy [Structural-parametric models of petrophysical parameters of the sedimentary cover of the Voronezh anteclise].
Izvestiya SO RAEN - Proceedings of the Siberian Department of the Section of Earth Sciences of the Russian Academy of Natural Sciences: Geology, Exploration and Development of Mineral Deposits, 2014, vol. 44, no. 1, pp. 81-87. (In Russ.)

13. Laske G., Masters G., Ma Z., Pasyanos M. Update on CRUST1.0 - A 1-degree Global Model of Earth's Crust. Abstract EGU2013-2658 presented at 2013 Geophys. Res. Abstracts. 2013. 15. EGU2013-2658. 14. Pasyanos M. E., Masters G., Laske G., Ma Z. LITHO1.0 : An updated crust and lithospheric model of the Earth. Journal Geophysical Research. Solid Earth, 2014, vol. 119, pp. 2153-2173. DOI: 10.1002/2013JB01062

15. Glaznev V. N., Yacouba I. A. Determining the thickness of the Earth's crust in the territory of the Republic of Niger based on the stochastic interpretation of the gravitational field. Vestnik Voronezhskogo gosudarstvennogo universiteta. Seriya: Geologiya - Proceedings of Voronezh State University. Series: Geology, 2020, no. 4, pp. 46-58. DOI: 10.17308/geology.2020.4/3126 (In Russ.)

16. Yacouba I. A., Glaznev V. N. The thickness of the Earth's crust in the territory of Republic of the Niger according to the stochastic interpretation of the gravity field. In: Kukkonen I.T., Veikkolainen T., Heinonen S., Karell F., Kozlovskaya E., Luttinen A., Nikkilä K., Nykänen V., Poutanen M., Skyttä P., Tanskanen E. and Tiira T. (Eds.). 2021. Lithosphere 2021 - Eleventh Symposium on the Structure, Composition and Evolution of the Lithosphere in Finland. Programme and Extended Abstracts, January 19-20, 2021. Institute of Seismology, University of Helsinki. Report S-71, pp. 157-160.

17. Brownfield M. E. Assessment of undiscovered oil and gas resources of the Chad Basin Province, north-central Africa. In Brownfield M.E. (Ed.) Geologic assessment of undiscovered hydrocarbon resources of Sub-Saharan Africa. 2016. U.S. Geological Survey Digital Data Series 69-GG. Chap. 6. 9 p. DOI: 10.3133/ds69GG

18. Lihong Z., Junqing S., Xiaowei D., Buqing S., Zhihua S., Maolu Q., Da L., Aiping L. Controlling factors of hydrocarbon accumulation in Termit rift superimposed basin, Niger. Petroleum Exploration and Development, 2017, vol. 44, no. 3, pp. 358-367. DOI: 10.1016/S1876-3804(17)30042-3

19. Perron P. Architecture and tectonic of Paleozoic intracratonic Basins : impact on the sedimentary record and associated geometries : example of peri-Hoggar Basins (North Gondwana marge). These de Doctorat. Université Bourgogne Franche-Comté. 2019. 394 p. NNT: 2019UBFCK022- tel-02284343

20. Ahmed K. S., Liu K., Paterne M. A., Kra K.L., Kuttin A. A.-A., Malquaire K.P.R., Ngum K.M.M.-A. Anatomy of Eastern Niger Rift Basin with Specific References of Its Petroleum Systems. International Journal of Geosciences, 2020, vol. 11, no. 5, pp. 305-324. DOI: 10.4236/ijg.2020.115016

21. Jessell M. W., Begg G. C., Miller M. S. The Geophysical Signatures of the West African Craton. Precambrian Research, 2016, vol. 274, no. 3, pp. 3-24. DOI: 10.1016/j.precamres.2015.08.010 22. Guiraud R., Maurin J.C. Early Cretaceous rifts of Western and Central Africa: an overview. Tectonophysics, 1992, vol. 213, pp. 153-168. DOI: 10.1016/0040-1951(92)90256-6

23. Genik G. J. Regional framework, structural and petroleum aspects of rift basins in Niger, Chad and the Central African Republic. Tectonophysics, 1992, vol. 213, pp. 169-185. DOI: 10.1016/00401951(92)90257-7

24. Greigert J. Description des formations cretacés et tertiaires du bassin des Iullemenden (Afrique occidentale). Ministere des Travaux publics, des Transports, des Mines et de l'Urbanisme de la republique du Niger. Direction des mines et de la geologie, 2. Paris, France. BRGM. 1966. 229 p.

25. Greigert J., Pougnet R. Notice explicative sur la carte geologique de la Republique du Niger à l'echelle du 1:2 000 000. Ministere de Travaux publics, des Transports, des Mines et de l'Urbanisme de la republique du Niger. Paris, France. BRGM. 1967-a. 62 p.

26. Greigert J., Pougnet R. Essai de description des formations geologiques de la republique du Niger. Ministere des Travaux publics, des Transports, des Mines et de l'Urbanisme de la republique du Niger. Direction des mines et de la geologie, 3. Paris, France. BRGM. 1967-b. 267 p. 
27. Clermonté J., Yahaya M., Lang J., Oumarou J. Un bassin paléozoïque et mésozoïque en décrochement : le Tim Mersoï dans la région d'Arlit, à l'Ouest de l'Aïr (Niger). Comptes rendus de l'Académie des sciences. Série 2, 1991, vol. 312, pp. 1189-1195.

28. Gaoh D. A. Etude des nappes aquiferes du Contiental Terminal entre les Dallols Bosso et Maouri, departement de Dosso, republique du Niger. Université de Liege, Belgique. These sciences. 1993. 258 p. 29. BGR \& ABN. Geological map of transboundary region of Benin, Niger and Nigeria: Sedimentary basins Iullemenden, Kandi, Sokoto. Berlin \& Niamey. 2019.

30. Avbovbo A., Ayoola E., Osahon G. Depositional and Structural Styles in Chad Basin of Northeastern Nigeria. AAPG Bulletin, 1986, vol. 70, pp. 1787-1798. DOI: 10.1306/94886D21-1704-11D7$8645000102 \mathrm{C} 1865 \mathrm{D}$

31. Genik G. J. Petroleum Geology of Rift Basins in Niger, Chad, and Central African Republic. AAPG Bulletin, 1993, vol.77, pp. 14051434. DOI: 10.1306/BDFF8EAC-1718-11D7-8645000102C1865D 32. Greigert J. Les eaux souterraines de la republique du Niger / Ministere des Travaux Publics, des Transports, des Mines et de l'Urbainisme de la republique du Niger. Rapport BRGM. Niamey, Niger. 1968. ABI 006 NIA. 2 volumes, $407 \mathrm{p}$.

33. Fairhead J.D. Geophysical Controls on Sedimentation within the African Rift Systems. In: Frostick L.E., Renaut R.W., et al., Eds. Sedimentation in the African Rifts. Geological Society, London, Special Publications, 1986, vol. 25, pp. 19-27. DOI: 10.1144/GSL.SP.1986.025.01.03

34. Bellion Y. Histoire geodynamique post-paleozoique de l'Afrique de l'Ouest d'apres l'etude de quelques bassins sedimentaires (Senegal, Taoudeni, IUllemenden, Tchad). Centre International pour la formation et les echanges Geologiques. CIFEG. 1987, vol. 17, 302 p. 35. Fairhead J. D., Green C.M. Controls on Rifting in Africa and the Regional Tectonic Model for the Nigeria and East Niger Rift Basins. Journal of African Earth Sciences, 1989, vol. 8, pp. 231249. DOI: $10.1016 / \mathrm{S} 0899-5362(89) 80027-2$

36. Zanguina M., Bruneton A., Gonnard R. An introduction to the petroleum potential of Niger. Journal Petroleum Geology, 1998, vol. 21 , no. 1, pp. 83-103. DOI: 10.1111/j.1747-5457.1998.tb00647.x 37. Davidson L., Beswetherick S., Craig J., Eales M., Fisher A., Himmali A., Jho J., Mejrab B., Smart J. The structure, stratigraphy and petroleum geology of the Murzuq Basin, southwest Libya. In: D. Worsley, M.A. Sola (Eds.). Geological Exploration in the Murzuq Basin. Elsevier Science. 2000, pp. 295-320. DOI: 10.1134/S0016702914060032

38. Liu B., Wan L.K., Mao F.J., Liu, J., Lu M.S., Wang Y. Hydrocarbon Potential of Upper Cretaceous Marine Source Rocks in the Termit Basin, Niger. Journal of Petroleum Geology, 2015, vol. 38 , pp. $157-175$. DOI: $10.1111 /$ jpg. 12604

39. Glaznev V. N., Loshakov G. G. About one method of modeling ore objects using adaptive approximation. Vestnik Voronezhskogo gosudarstvennogo universiteta. Seriya: Geologiya - Proceedings of Voronezh State University. Series: Geology, 2012, no. 1, pp. 243246. (In Russ.)

40. Muravina O.M., Loshakov G.G. Principles of solving direct problems of potential in modeling the structure of the lithosphere. Vestnik Voronezhskogo gosudarstvennogo universiteta. Seriya:Geologiya - Proceedings of Voronezh State University. Series:
Geology, 2015, no. 3, pp. 97-100. (In Russ.)

41. Nguimbous-Kouoh J. J., Ndougsa-Mbarga T., Njandjock-Nouck P., Eyike A., Campos-Enriquez J. O., Manguelle-Dicoum E. The structure of the Goulfey-Tourba sedimentary basin (ChadCameroon): a gravity study. Geofisica Internacional, 2010, vol. 49, no. 4, pp. 181-193. DOI: 10.22201/igeof.00167169p.2010.49.4.127 42. Amante C., Eakins B. W. ETOPO1 - 1 Arc-Minute Global Relief Model: Procedures, Data Sources and Analysis. NOAA Technical Memorandum NESDIS NGDC-24. National Geophysical Data Center, NOAA, 2009. DOI: 10.7289/V5C8276M

43. De Marsily G. Hydrogeologie: comprendre et estimer les ecoulements souterrains et le transport des polluants. Cours de l'ecole des Mines de Paris. France, Paris. 1994. 243 p.

44. Muhammad N.N., Lo S.-Z., Abdul G.M.R. Petrophysical analysis of E5 sand group of Sokor formation, Termit basin, Niger. IOP Conf. Series: Earth and Environmental Science, vol. 88, N 012003 2017. DOI: $10.1088 / 1755-1315 / 88 / 1 / 012003$

45. Muhammad S.Z.M., Lo S.-Z., Abdul G.M.R. Petrophysical Analysis on Radioactive Sands for Koala Field in Termit Basin, Niger. Journal of Engineering and Applied Sciences, 2018, vol. 13, no. 13 , pp. 5122-5130. DOI: $10.36478 /$ jeasci.2018.5122.5130

46. Li Z., Cheng X., Jiang H., Zheng F. Genetic mechanism of lowresistivity oil zones and comprehensive identification technology for well logging in the Termit Basin. Niger. Science Frontiers, 2018, vol. 25, no. 2, pp. 099-111. DOI: 10.13745/j.esf.2018.02.011

47. Ning Z., Xia G., Jiangqin H., Zhongmin C., Guangya Z. Sedimentary characteristics and lithological trap identification of Distant Braided delta deposits: a case on upper Cretaceous Yogou formation of Termit Basin, Niger. $3^{\text {rd }}$ International Conference on Advances in Energy and Environment Research. Abstracts. 2018, vol. 53. DOI: 10.1051/e3sconf/20185303020

48. Lai H., Li M., Mao F., Liu J., Xiao H., Tang Y., Shi S. Source rock types, distribution and their hydrocarbon generative potential within the Paleogene Sokor-1 and LV formations in Termit Basin, Niger. Energy Exploration \& Exploitation, 2020, vol. 38 (6), pp. 2143-2168. DOI: 10.1177/0144598720915534

49. Galitchanina L. D., Glaznev V. N., Mitrofanov F. P., Olesen O., Henkel H. Surface density characteristics of the Baltic Shield and adjacent territories. Norges Geologiske Undersokelse, 1995, Special Publ, vol. 7, pp. 349-354.

50. Shipilov E. V., Tyuremnov V. A., Glaznev V. N., Golubev V. A. Paleogeograficheskie obstanovki i tektonicheskie deformatsii Barentsevomorskoi kontinental'noi okrainy v kainozoe [Paleogeographic settings and tectonic deformations of the Barents Sea continental margin in the Cenozoic]. Doklady AN - Reports of the Academy of Sciences, 2006, vol. 407, no. 3, pp. 378-383.

51. Muravina O. M. Identifikatsionnyi analiz petrofizicheskikh kharakteristik porod osadochnogo chekhla Voronezhskoi anteklizy [Identification analysis of petrophysical characteristics of rocks of the sedimentary cover of the Voronezh anteclise]. Vestnik KRAUNTS. Ser.: Nauki o Zemle - The KRAUNZ Herald. Ser.: Earth Sciences, 2013, no. 2 (22), pp. 20-25. (In Russ.)

52. Kartvelishvili K. M. Planetarnaya plotnostnaya model' i normal'noe gravitatsionnoe pole Zemli [Planetary density model and normal gravitational field of the Earth.]. Moscow, Nauka publ., 1983, 93 p. (In Russ.)
Глазнев Виктор Николаевич - д.ф.-м.н., профессор, заведующий кафедрой геофизики, Воронежский государственный университет, Воронеж, Российская Федерация;

E-mail: glaznev@geol.vsu.ru; ORCID https://orcid.org/0000-0002-1016-1866

Якуба Ибрагим Абдоу - аспирант кафедры геофизики, Воронежский государственный университет, Воронеж, Российская Федерация; E-mail: yibrahimabdou@yahoo.fr Авторы прочитали и одобрили окончательный вариант рукописи.
Victor N. Glaznev - Dr.habil. in Geophysics and Mathematics, Professor, Head of the Department of Geophysics, Voronezh State University, Voronezh, Russian Federation;

E-mail: glaznev@geol.vsu.ru;

ORCID https://orcid.org/0000-0002-1016-1866

Ibrahim A. Yacouba - postgraduate student, Department of Geophysics, Voronezh State University, Russian Federation; E-mail: yibrahimabdou@yahoo.fr

The authors have read and approved the final manuscript. 